Baiba Rivža, Andra Zvirbule, Maiga Krūzmētra

\title{
Tautsaimniecības lineāro un strukturālo izmaiṇu virzība Covid-19 laikā
}

Pētījuma mērķis ir analizēt jau notikušās un nākotnē paredzamās strukturālās izmaiṇas globālajā ekonomikā un Latvijā.

\section{Krīzes ietekme uz strukturālajām izmaiṇām uzṇēmumu līmenī}

Saskaņā ar Ekonomiskās sadarbības un attīstības organizācijas datiem (ESAO, 2020) Covid-19 pandēmija tiek uzskatīta par vienu no lielākajām krīzēm, kas skar ne tikai ekonomiku un tautsaimniecību, bet arī vienlaikus sabiedrības veselību un sabiedrības noskaņojumu. Šādas pārmaiṇas ekonomiskajā sistēmā nav novērotas bieži un principā ir asociējamas ar globāla līmeṇa kara izraisītām sekām. Vairāku autoru pētījumos ${ }^{1,2,3}$ tiek atzìts, ka Covid-19 pandēmija ir liels eksogēns šoks, kas ir mainījis konkurences laukumu, patēriņa un patērētāju uzvedību, radijis uzṇēmuma mikroklimata izmaiņas gan maziem, gan lieliem uzñēmumiem, gan valsts pārvaldē. Daudzos gadījumos pandēmija ir izraisījusi pieprasījuma procesu sabrukumu un būtiski traucējusi produktu, materiālu un izejvielu piegādes k̦ēdes. Reaǵējot uz krīzi, valdības visā pasaulē ir slēgušas robežas, ieviesušas sociālās

1 Brada, J. C., Gajewski P., Kutan, A. M. (2021). Economic resiliency and recovery, lessons from the financial crisis for the COVID-19 pandemic: A regional perspective from Central and Eastern Europe, International Review of Financial Analysis, Vol. 74. Pieejams: https://doi.org/10.1016/j.irfa.2021.101658

2 Padhan, R., Prabheesh, K. P (2020). The economics of COVID-19 pandemic, Economic Analysis and Policy, Vol. 70, June, pp. 220-237.

3 Shen, H., Fu, M., Pan, H., Yu, Z., Chen, Y. (2020). The impact of the COVID-19 pandemic on firm performance, Emerg. Mark. Finance Trade, 56 (10), pp. 2213-2230. 
distancēšanās pasākumus, kā arī noteikušas ierobežojumus un drošības vadlīnijas mazajiem, vidējiem un lielajiem uzṇēmumiem. Šãdi nosacỉjumi ir radījuši izmaiņas tautsaimniecības sistēmās, un uzņēmumi ir spiesti tām pielāgoties.

Savukārt uzņēmumu līmenī vērojamas strukturālas izmaiņas, kas skar uzñēmējdarbības mikrovidi, - darbinieku distancēšanās darba vidē, attālināts darbs, saīsinātas darba stundas, papildu laika un darba grafiki. Bet vairāki uzṇēmumi ir savu darbību slēguši, tādējādi pilnībā mainot noteiktu nozaru līdzsvaru un ietekmējot nozaru lejupslīdi. Pēc Latvijas Bankas ${ }^{4}$ un Pasaules Bankas datiem ${ }^{5}$ un vērtējumiem, visvairāk skarta ir aviopārvadājumu nozare, tūrisma nozare, biroju īres, kā arī darījumu braucienu, konferenču, izstāžu, kultūras pasākumu organizēšanas uzṇēmējdarbỉba.

Pēc Eiropas Investīiju bankas $(2020)^{6}$ aplēsēm, pandēmija ir radījusi pieprasijuma un piedāvājuma šoku visai mazo un vidējo uzṇēmumu grupai, kas ir Eiropas ekonomikas mugurkauls un kas veido vairāk nekā 55\% no pievienotās vērtības tieši nefinanšu uzṇēmējdarbības nozarēs. Pēkšņais uzņēmējdarbības vides šoks, ko izraisīja Covid-19, lielu ietekmi uz tautsaimniecību ir radījis caur uzņēmumu spēju pārorientēt finanšu resursus, noturēt maksātspēju un veidot uzņēmumu dzìvotspēju tā, lai pēcpandēmijas posmā uzņēmumi varētu atgriezties tautsaimniecībā un noturēt konkurētspēju. Finansiālas grūtības organizācijās un finanšu stāvokḷa pavājināšanās liek valstu komercbankām un uzṇēmēju apvien̄ibām, uzraugot mikroekonomikas tendences, meklēt valdības atbalstu - subsīdiju, nodokḷu atlaižu un cita veida finansiālu palīdzību, kā arī nefinansiālu atbalstu (Eiropas Komisijas dati, 2020). ${ }^{7}$

Lielā mērā daudzu nozaru uzṇēmumi (ražošanas uzṇēmumi, lielie uzṇēmumi, pārtikas pārstrādes uzṇēmumi u. c.) ir spiesti "sacensties epidemiolog̣isko nosacijumu jomā", atbilstoši iekārtojot savas ražošanas telpas un izpildot epidemiologiskos nosacijumus, lai samazinātu vīrusu pārnešanas potenciālu. Šādas darbības rada papildu slodzi vadības līmenim, jo laiks un uzmanība tiek pievērsta daudzām blakus darbībām, kas turklāt nepārtraukti mainās, no tiešās saimnieciskās darbības, kas vērsta uz preču ražošanu, uz pārdošanu un/vai pakalpojumiem, kā dēḷ samazinās pamatdarbību efektivitāte un produktivitāte. Turklāt aizņēmumu biznesa modẹ̦i pirms pandēmijas bija koncentrēti uz pieņēmumiem, ka

4 Makroekonomisko norišu pārskats. Pieejams: https://www.makroekonomika.lv/makroekonomisko-norisu-parskats-2020-gada-septembris [skatīts 20.02.2021.]

5 Global Economic Prospects. (2021). Pieejams: https://www.worldbank.org/en/publication/global-economic-prospects [skatits 11.03.2021.]

6 European Investment Bank Activity Report 2020. Pieejams: https://www.eib.org/en/publications/activity-report-2020.htm\# [skatīts 03.03.2021.]

The EU budget powering the Recovery Plan for Europe. Pieejams: https:/ec.europa.eu/info/files/ eu-budget-powering-recovery-plan-europe_en [skatits 03.03.2021.] 
nākotnes uzṇēmējdarbības vide būtu pietiekami paredzama un krīzes situācijas ir risināmas ar vairākiem krīzes novēršanas vai pārvarēšanas instrumentiem. Taču pašreizējos apstākḷ̆os šie instrumenti nedarbojas, un arī biznesa model̦a stabilitāte ir izjaukta.

\section{Strukturālās izmaiṇas ietekmējošie faktori}

Vadoties pēc procesu modeḷa (1. attēls), kas ietekmē krasas strukturālās izmaiṇas vai arī noved pie neveiksmes, kā ietekmējošie faktori ir minēti gan ārējie, gan iekšējie faktori. Covid-19 pandēmijas laikā, bet īpaši beidzoties saspīlētai situācijai un spriedzei un sākot tautsaimniecỉbas strukturālās izmaiņas pēcpandēmijas atveseḷošanās posmā, nozīmīgi ir izprast daudzo ietekmējošo faktoru kopsakarības.

Institucionālais jeb ārējās ietekmēs faktors, kas vairākos pētijumos ${ }^{8,9}$ tiek aprakstīts kā Covid-19 pandēmijas laikā valdību pieņemto lēmumu ietekme uz institucionālo vidi, kas rada uzņēmējdarbībai iekšējos izaicinājumus un nepieciešamību krasi pārkārtot biznesa modeli vai arī veikt lineāras un strukturālas izmaiņas. Šāda neatbilstība pandēmijas situācijā ir novērota gandrīz visās valstīs, un tie ir lēmumi un kārtība par ārējām prasībām, piemēram, valdības noteiktie epidemiologiskie standarti, noteikumi un direktīvas. Bieži vien šādas biznesa vides trauksme izriet no pieṇēmumiem par ilgu regulējumu darbības laiku, kas ierobežo biznesa aktivitātes, nav pārliecības par lēmumu nepārtrauktību un/vai prognozes par turpmāko valdības politiku. Galvenais aspekts, kas vairākās nozarēs ir bijis svarīgākais ietekmes faktors, - robežu slēgšana, kā arī jaunas viesmīlības, aviokompāniju un citu nozaru direktīvas, kuru mērķis ir ierobežot cilvēku kustību. Turklāt valdības iejaukšanās veselības aprūpes preču globālajā tirdzniecībā un jauni tarifi, lai aizsargātu valsts stratēgiskās nozares, ir būtiski mainījuši spēes noteikumus atsevišḳās tautsaimniecības jomās. Lai gan Covid-19 pandēmija vienlīdz ietekmējusi institucionāli visu mazo un vidējo uzņēmumu darbību, daudziem uzṇēmumiem trūkst spējas ātri mainīt uzṇēmējdarbības modeli atbilstoši jaunajām prasībām.

8 Janssen, M., Voort, H. (2020). Agile and adaptive governance in crisis response: Lessons from the COVID-19 pandemic, International Journal of Information Management, Vol. 55, December. Pieejams: https://doi.org/10.1016/j.ijinfomgt.2020.102180

9 Makin, A. J. (2019). Lessons for macroeconomic policy from the Global Financial Crisis, Economic Analysis and Policy, Vol. 64, pp. 13-25. 


\section{1. attēls. Vispārējs ārējo un iekšējo procesu modelis Covid-19 pandēmijas laikā, kas noved pie krasām strukturālām izmaiṇām vai neveiksmēm}

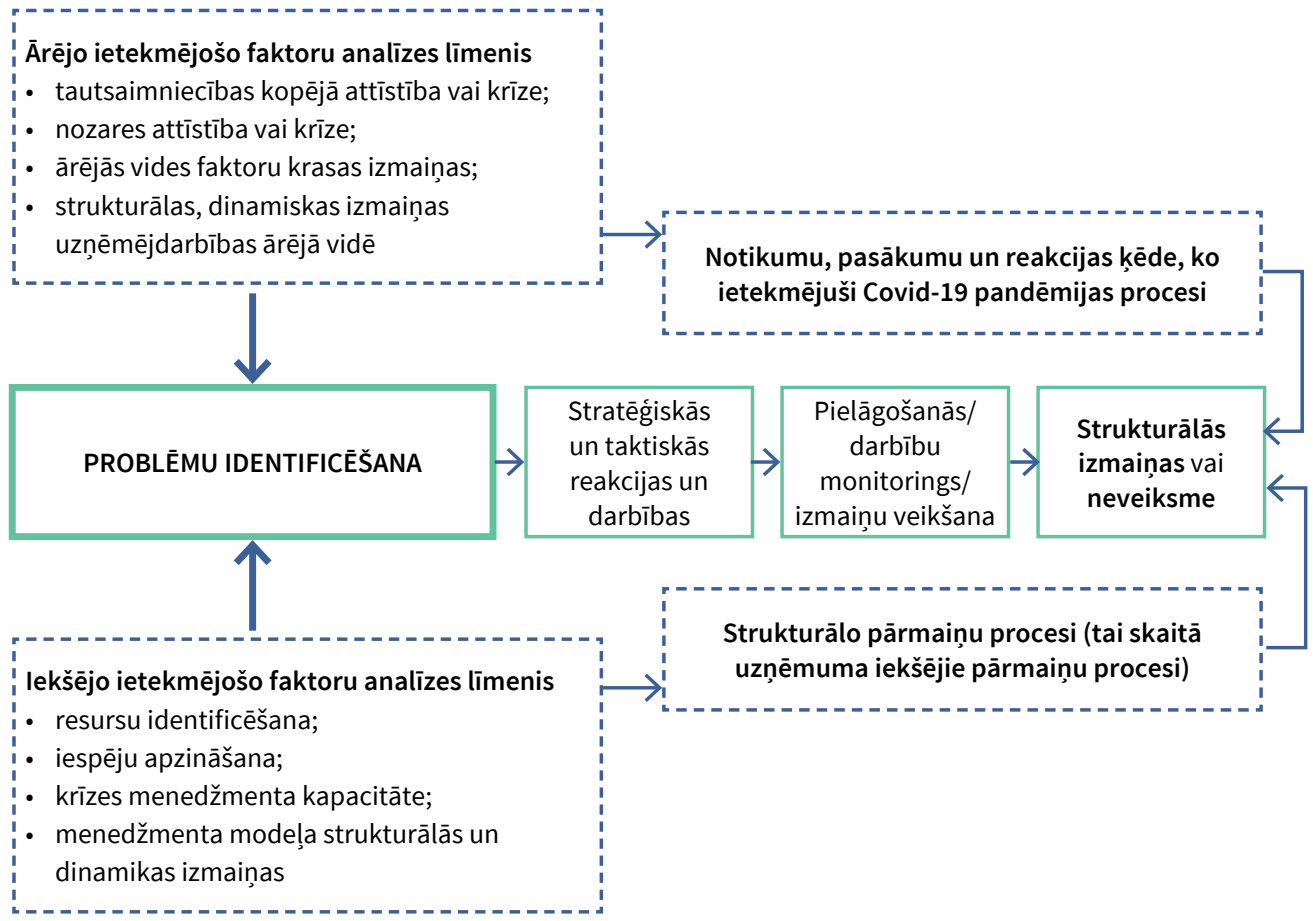

Kā redzams no vairāku veikto aptauju kopsavilkumiem (2. attēls), tad visā Eiropā situācija ir samērā vienlīdzīga, kas ietver finansiālo spiedienu un spriedzi uz uzņēmējdarbības modeḷiem, turklāt liela dạ̧a uzņēmumu risina arī sociālo funkciju - piedāvājot darbiniekiem atbalstu. Tomēr vairums valstu uzṇēmēju atzīst, ka valdības regulējums ES iekšienē ir bijis nevienmērīgs un slikti koordinēts starptautiskā mērogā, tādējādi izraisot konkurējošas prasības uzṇēmumiem, kas ir eksportspējīgi un konkurē globālajos tirgos. Attiecīgi tas ietekmē stratēgisko attīstību, ko parāda arī aptaujā atbildes uz menedžmenta funkcijas nodrošinājumu. Tradicionāli tiek uzskatìts, ka institucionālo prasību konteksta daudzveidība rada uzṇēmumos spiedienu veikt bieži vien ātras un nepārdomātas

10 Amankwah-Amoah, J., Khan, Z., Wood, G. (2020). COVID-19 and business failures: The paradoxes of experience, scale, and scope for theory and practice, European Management Journal, September. Pieejams: https://doi.org/10.1016/j.emj.2020.09.002 
pārmaiṇas - modificēt savu uzvedību, procesus, darbības metodes un sistēmas, lai sasniegtu institucionālo piemērotību. Taču šādām strukturālām izmaiņām ir īstermiņa ieguvumi, bet sekas var būt ilglaicīgas. To pierāda arī tas, ka 72,3\% no atjaunotajiem uzṇēmumiem nav pārliecināti par savu ilgtermiṇa veiksmi Covid-19 pārvarēšanā.

\section{2. attēls. Uzṇēmēju viedoklis par atsevišḳu funkciju veikšanu Covid-19 laikā}

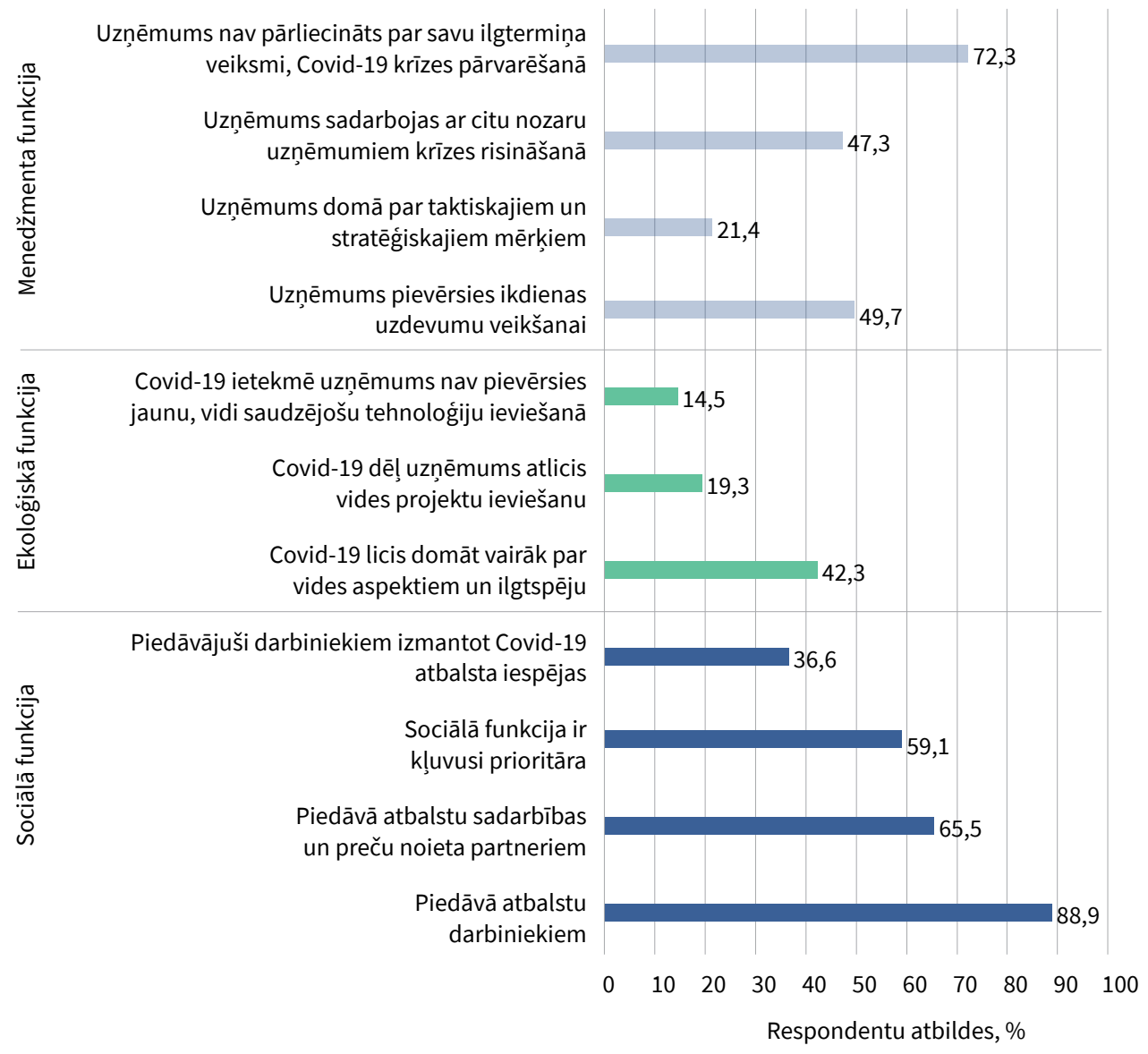

Avots: autoru apkopojums pēc svarīguma, balstoties uz Euromonitor ${ }^{11}$ un ESAO ${ }^{12}$ datiem.

11 Introducing Euromonitor's Coronavirus Economic Scenarios. Pieejams: https://www.euromonitor. com/the-impact-of-coronavirus-on-the-global-economy/report

12 OECD Economic Outlook. (2021). Pieejams: https://www.oecd-ilibrary.org/docserver/34bfd999-en.pdf ?expires $=1616243346 \& \mathrm{id}=\mathrm{id} \&$ accname $=$ guest $\&$ checksum $=4$ FF3A6E1E835637D44F8563F14FDE6DE [skatits 09.03.2021.] 


\section{Nodarbinātība kā Latvijas tautsaimniecības strukturālo izmaiṇu indikators}

Sociālās funkcijas aspektu analīzē būtiski ir vērtēt nodarbinātību, kas, no vienas puses, ir saistīta ar uzṇēmējdarbības sociālo vidi, bet, no otras puses, veicina noteiktu nozaru radītā produkta un pakalpojuma patēriņu. 2020. gadā Latvijā Covid-19 pandēmijas laikā tautsaimniecības sistēmā nodarbināto skaits ir samazinājies kopumā par 3,4\%. Tomēr darba vietu "zudums" ārpus lielajām pilsētām uzrāda daudz augstākus rādītājus - pilsētās samazinājums ir nepilns procents, novados tas tuvojas $10 \%$ atzīmei. Tas varētu būt skaidrojams ar mikrouzṇēmumu lielas daḷas izvietošanos laukos, ar uzṇēmējdarbībā iesaistīto ierobežotām digitālajām prasmēm, patēētāju struktūru, nodarbinātības struktūru un līdz ar to arī sarežg̀itāku valsts sniegtā atbalsta saņemšanu uzņēmējdarbības aktivitāšu uzturēšanai. Šādu pieņēmumu arī apstiprina dati 1. tabulā, kurā parādīts nodarbināto skaita izmaiñas Covid-19 pandēmijas periodā, tieši privātajā sektorā nodarbināto skaits, kur komersanti nodarbina mazāk nekā 50 cilvēkus.

\section{1. tabula. Privātajā sektorā nodarbināto skaits` un izmaiṇu salīdzinājums republikas pilsētās un novados (2019. gada 4. ceturksnis - 2020. gads, tūkst.)}

\begin{tabular}{|c|c|c|c|c|c|c|}
\hline & 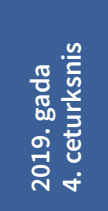 & 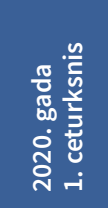 & 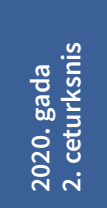 & 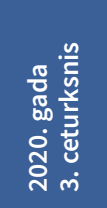 & 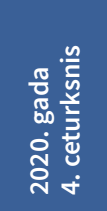 & 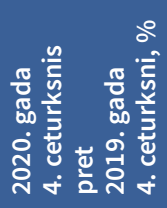 \\
\hline Latvijā kopā & 251891 & 252818 & 234705 & 246032 & 243332 & 96,60 \\
\hline 9 pilsētas & 175370 & 182784 & 166571 & 174740 & 173753 & 99,07 \\
\hline 110 novadi & 76521 & 70034 & 68134 & 71292 & 69579 & 90,92 \\
\hline
\end{tabular}

*Privātā sektora komersanti ar nodarbināto skaitu >=5013 Avots: CSP dati.

Viskrasākās izmaiņas nodarbinātībā ir vērojamas Latvijas regionos, kur joprojām būtiski atškiras ekonomiskā aktivitāte un attiecīgi darba vietu nozīmīgākais īpatsvars lielākās pilsētās, kas bija vērojams arī pirms pandēmijas. Tādējādi

13 Vidējais darbinieku skaits normālā darba laika vienībās regionos, republikas pilsētās un novados. Pieejams: https://data.stat.gov.lv/pxweb/lv/OSP_PUB/START__EMP__DV__DVA/DVA070c/table/tableViewLayout1/ [skatīts 20.03.2021.] 
pēckrīzes situācijā izteiktāka darbaspēka nepietiekamība būs Rīgā un Pierīgā, kas piesaistīs darba meklētājus arī no citiem reǵioniem. Taču Covid-19 pandēmijas seku dēl ir samazinājies Nodarbinātības valsts aǵentūrā reǵistrēto vakanču skaits. Aǵentūras sniegtā informācija liecina, ka 2020. gadā brīvo darba vietu bija par 28\% mazāk nekā 2019. gadā pieteikto brīvo darba vietu skaits. Lìdz ar to notikušas nodarbinātības strukturālās izmaiṇas, kas liek secināt, ka mazo un vidējo uzṇēmumu darbinieki, kas zaudējuši darbu vienā tautsaimniecības nozarē, pārkvalificējas un meklē darbu kādā citā nozarē, lai nezaudētu pastāvīgus ienākumus.

Veicot padziḷinātu analīzi reǵionu skatījumā, iegūstam diferencētus rezultātus, kas apkopoti 2. tabulā.

\section{2. tabula. Nodarbināto skaits un izmainu salīdzinājums reǵionos}

(2019. gada 4. ceturksnī - 2020. gadā, tūkst.)

\begin{tabular}{|c|c|c|c|c|c|c|}
\hline & 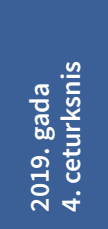 & 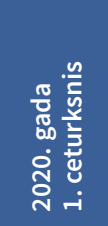 & 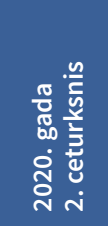 & 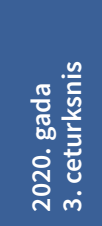 & 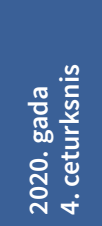 & 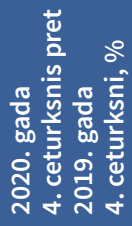 \\
\hline Latvijā kopā & 763852 & 749307 & 706176 & 735635 & 728638 & 95,39 \\
\hline Rīgas reǵions & 416017 & 417512 & 386619 & 401761 & 398654 & 95,82 \\
\hline Pierīgas regions & 122153 & 113915 & 107381 & 112172 & 110749 & 90,66 \\
\hline Vidzemes regions & 49397 & 47521 & 46422 & 48198 & 47301 & 95,75 \\
\hline Kurzemes reǵions & 65290 & 61985 & 60610 & 63595 & 62798 & 96,18 \\
\hline Zemgales regions & 56342 & 54508 & 53032 & 55720 & 55434 & 98,38 \\
\hline Latgales regions & 54638 & 53860 & 52096 & 54175 & 53692 & 98,26 \\
\hline
\end{tabular}

Avots: CSB dati un autoru aprēḳini. ${ }^{14}$

Analizējot nodarbināto skaita un izmaiṇu salīdzinājumu Latvijas reǵionu skatījumā, iegūstam rezultātus, kas liecina, ka nodarbinātība pa reǵioniem ir saglabājusies diezgan atšķirīga. Viszemākā darba vietu saglabāšana ir bijusi Pierīgas

14 Aizṇemtās darba vietas regionos, republikas pilsētās un novados ceturkšṇa beigās. Pieejams: https:// stat.gov.lv/lv/statistikas-temas/darbs/darbvietas-darbalaiks/tabulas/dva020c-aiznemtas-darbvietas-regionos [skatīts 20.03.2021.] 
regiionā, augstākā - Zemgales $(98,4 \%)$ un Latgales $(98,3 \%)$ reg̣ionos. Vērtējot izmaiņas pa ceturkšņiem, viskrasākās izmaiņas ir notikušas 2020. gada pirmajā un otrajā ceturksnī. 2020. gada pirmajā ceturksnī salīdzinājumā ar iepriekšèjā gada pēdējo ceturksni 5-7\% samazinājums ir bijis Pierīgas un Kurzemes reǵionā. 2020. gada trešajā ceturksnī nodarbinātības atveseļošanās procesi visstraujāk notikuši Kurzemes un Zemgales reg̣ionā.

Pandēmija ir ieviesusi àtras un neatgriezeniskas sekas atsevišḳu nozaru struktūrās, un nozaru strukturālās reformas būs nepieciešamas, lai uzlabotu krīzes noturību, atvieglotu pārdalǐšanu un stiprinātu izaugsmes iespējas. Visās ES valstīs pēcpandēmijas fāzē būs jāveic strukturālās reformas, lai radītu iespējas pārvietoties darba n̦ēmējiem, uzlabotu ekonomikas dinamiku un veicinātu resursu pārdali atsevišķās nozarēs, un ieguldītu darbībās, kas stiprina izaugsmi, uzlabo noturību un veicina vides ilgtspèjību. Pēc ESAO datiem (3. attēls), varam secināt, ka Covid-19 krīze, visticamāk, prasīs zināmu darbaspēka un kapitāla pārdali, lai gan tās apmērs joprojām nav skaidrs, jo ir vērojamas nepārtrauktas dinamiskas izmaiņas nozaru un jomu skatijumā.

\section{3. attēls. Jaunu darba vietu pieprasījuma izmaiṇas, \% globālā skatījumā}

(2021. gada februāris - 2020. gada aprīlis)

Pārtikas produktu ražošanas/pārstrādes sfēra

Klientu apkalpošana

Administratīvais darbs

Izglītības sfēra

Bizness un finanses

Ražošanas joma

Veselības aprūpe

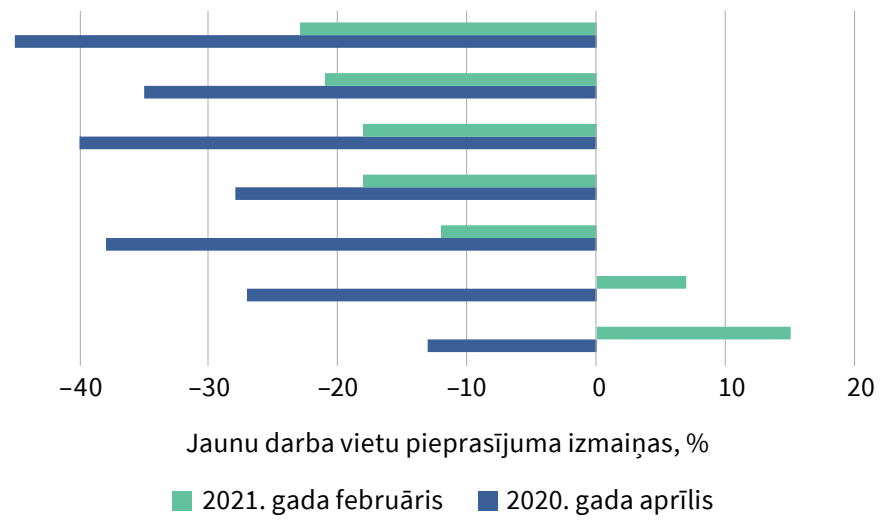

Avots: Eurofound dati (2021). ${ }^{15}$

Tātad atsevišķu jomu un veidu atkopšanās notiek, neskatoties uz neskaidriem apstākḷiem un nepārtrauktām ārējās vides izmaiṇām. Dažas nozares, kuras

\footnotetext{
15 Living, working and COVID-19. Pieejams: https://www.eurofound.europa.eu/
} 
visvairāk ietekmē fiziskās distancēšanās prasības un ar tām saistītās izmaiṇas patērētāju vēlmēs, pēc krīzes tautsaimniecības īpatsvarā varētu samazināties. Ilgstoša pāreja uz attālinātu darbu, biznesa ceļojumu samazināšana un pieaugošā pakalpojumu digitālā piegāde, ieskaitot e-komerciju, arī varētu mainīt pieejamo darba vietu skaitu un daudzu darba vietu atrašanās vietu. Šādas potenciālas pārmaiņas ilgstošā laika periodā var radīt problēmas, un tautsaimniecība var ieslīgt vājas izaugsmes fāzē, kas palielinātu ekonomisko nevienlīdzību un piekḷuvi iespējām, kā arī nepieciešamību pielāgoties digitalizācijai un klimata pārmaiņām.

Latvijā lineārās tautsaimniecības izmaiṇas analizētajā laika periodā (2020.2019. gads) izpaužas pirmām kārtām kā nodarbināto skaita pieaugums vai samazinājums attiecīgajā tautsaimniecỉbas sistēmas pamatsegmentā pa nozarēm un regioniem (3. tabula). Tas ir tikai viens no lineārās izmaiņas indikatoriem. Vērtējot tautsaimniecības rādītāju kopsakarības un veicot kvalitatīvu analīzi dinamikā, mēs varētu izdarìt vairāk secinājumus par Covid-19 pandēmijas ietekmi uz tautsaimniecības strukturālajām izmaiņām. Šãdas izmaiņas būtu jāvērtē kopsakarībā ar uzņēmējdarbības pamatjomu neto apgrozījumu, produkcijas noieta procentuālo daḷu eksportā un citiem rādītājiem. Galvenais izvērtējuma akcents ir, vai lineārā izaugsme kādā no pamatsegmentiem virza valsts un sabiedrības ilgtspējīgu attīstību pasaules mainīgajos apstākḷos. Tomēr arī tikai nodarbināto skaita analīze palīdz izdarìt svarīgus secinājumus.

Vērtējot nodarbināto skaita izmaiņas un salīdzinot tās, varam iegūt iezīmes par tām darbības jomām, kuras Covid-19 pandēmija nav būtiski ietekmējusi, kā arī vērtēt tās jomas, uz kurām darbaspēka plūsma ir pārorientējusies. Pèc nodarbināto skaita izmaiņām 2020. gadā varam pieņemt, ka lineāra izaugsme reǵionos uzrāda gan kopējas, gan atšķirīgas iezīmes, un tas izraisa daudz jautājumu, kuri pēc papildu datu saņemšanas ir padziļināti jāanalizē.

Salīdzinot 2019. gada 4. ceturksni ar 2020. gada 4. ceturksni, varam secināt, ka atsevišķas nozares - lauksaimniecība, ieguves rūpniecība, IKT pakalpojumi, valsts pārvalde, izglītība un veselības joma (tabulā gaiši zal̦š fons) nav piedzivojušas būtiskas izmaiṇas, kas skartu nodarbināto skaita izmaiṇas Covid-19 pandēmijas kontekstā. Taču citas nozares - transports un uzglabāšana un apkalpojošo dienestu darbības joma (tabulā tumši zal̦š fons) - ir piedzīvojušas darbinieku vidējā līmeņa kritumu. Savukārt izmitināšanas un ēdināšanas pakalpojumi un citi pakalpojumi, kuros ietilpst individuālo pakalpojumu sniegšana (tabulā zils fons), ir piedzīvojuši krasas izmaiṇas, būtiski ietekmējot arī kopējo nodarbināto skaita izmaiṇas. 


\section{3. tabula. Nodarbināto skaita izmainas pa tautsaimniecības sistēmas pamatsegmentiem} (2019. gada 4. ceturksnis - 2020. gada 4. ceturksnis)

\begin{tabular}{|c|c|c|c|c|c|c|c|}
\hline $\begin{array}{c}\text { Aizṇemtās darba vietas reǵionos pa } \\
\text { darbības veidiem } \\
\text { (2019. gada 4. ceturksnis/2020. gada } \\
\text { 4. ceturksnis) }\end{array}$ & 莺 & 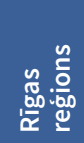 & 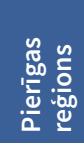 & 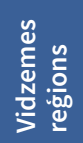 & 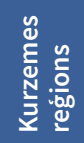 & 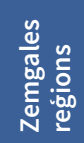 & 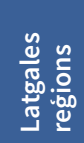 \\
\hline PAVISAM & 0,965 & 0,972 & 0,916 & 0,961 & 0,976 & 0,992 & 0,986 \\
\hline $\begin{array}{l}\text { (A) Lauksaimniecība, mežsaimniecība } \\
\text { un zivsaimniecība }\end{array}$ & 1,006 & 0,947 & 1,006 & 1,051 & 0,987 & 1,006 & 1,045 \\
\hline $\begin{array}{l}\text { (B) leguves rūpniecība un karjeru } \\
\text { izstrāde }\end{array}$ & 1,102 & 1,237 & 1,125 & 0,985 & 1,722 & 0,888 & 1,056 \\
\hline (C) Apstrādes rūpniecība & 0,995 & 0,977 & 1,010 & 0,964 & 0,984 & 1,041 & 1,022 \\
\hline $\begin{array}{l}\text { (D) Elektroenerǵija, gāzes apgāde, } \\
\text { siltumapgāde un gaisa } \\
\text { kondicionēšana }\end{array}$ & 0,970 & 0,981 & 1,005 & 0,851 & 0,923 & 1,031 & 0,982 \\
\hline $\begin{array}{l}\text { (E) Ūdens apgāde; notekūdeņu, } \\
\text { atkritumu apsaimniekošana un } \\
\text { sanācija }\end{array}$ & 0,959 & 0,907 & 0,930 & 1,223 & 0,954 & 0,999 & 1,006 \\
\hline (F) Būvniecība & 0,977 & 0,959 & 1,098 & 0,844 & 0,989 & 0,990 & 0,942 \\
\hline $\begin{array}{l}\text { (G) Vairumtirdzniecība un } \\
\text { mazumtirdzniecība; automobiļu un } \\
\text { motociklu remonts }\end{array}$ & 0,957 & 1,032 & 0,753 & 0,921 & 0,971 & 0,963 & 0,910 \\
\hline (H) Transports un uzglabāšana & 0,906 & 0,891 & 0,843 & 0,989 & 0,990 & 0,921 & 1,129 \\
\hline $\begin{array}{l}\text { (I) Izmitināšanas un ēdināšanas } \\
\text { pakalpojumi }\end{array}$ & 0,688 & 0,604 & 0,734 & 0,942 & 0,766 & 1,056 & 0,841 \\
\hline $\begin{array}{l}\text { (J) Informācijas un komunikācijas } \\
\text { pakalpojumi }\end{array}$ & 1,027 & 1,037 & 0,982 & 0,922 & 0,876 & 1,064 & 1,039 \\
\hline (K) Finanšu un apdrošināšanas darbības & 0,960 & 0,956 & 1,030 & 0,882 & 1,303 & 0,931 & 0,659 \\
\hline (L) Operācijas ar nekustamo īpašumu & 0,971 & 0,982 & 0,976 & 0,981 & 0,829 & 1,019 & 0,994 \\
\hline $\begin{array}{l}\text { (M) Profesionālie, zinātniskie un } \\
\text { tehniskie pakalpojumi }\end{array}$ & 0,958 & 0,948 & 0,900 & 1,374 & 0,855 & 1,043 & 0,984 \\
\hline $\begin{array}{l}\text { (N) Administratīvo un apkalpojošo } \\
\text { dienestu darbība }\end{array}$ & 0,916 & 0,924 & 0,894 & 0,809 & 0,862 & 0,827 & 1,087 \\
\hline $\begin{array}{l}\text { (0) Valsts pārvalde un aizsardzība; } \\
\text { obligātā sociālā apdrošināšana }\end{array}$ & 1,013 & 1,013 & 0,997 & 1,009 & 1,060 & 1,004 & 0,997 \\
\hline (P) Izglītība & 1,012 & 1,059 & 0,971 & 0,954 & 1,015 & 0,987 & 0,980 \\
\hline (Q) Veselība un sociālā aprūpe & 1,036 & 1,046 & 1,036 & 1,012 & 1,067 & 0,985 & 1,019 \\
\hline (S) Citi pakalpojumi & 0,896 & 0,954 & 0,731 & 0,791 & 0,917 & 0,986 & 0,651 \\
\hline
\end{tabular}

Avots: CSP dati. Aizņemtās darba vietas reǵionos pa darbības veidiem ceturkšņa beigās, autoru aprēḳini. ${ }^{16}$

16 Aizņemtās darba vietas reǵionos pa darbības veidiem ceturkšņa beigās. Pieejams: https://data.csb.gov.lv/ pxweb/lv/sociala/sociala__aiznemtdv__isterm/JVS014c.px/table/tableViewLayout1/ [skatits 20.03.2021.] 
Vērtējot izmaiṇas pa reǵioniem, varam konstatēt, ka pat vienā tautsaimniecības sfērā ir dažādas, bieži vien pretējas tendences. Piemēram, izmitināšanas un ēdināšanas pakalpojumu jomai ir bijušas viskrasākās negatīvās izmaiṇas Rīgas reǵionā ir vērojams būtisks nodarbināto kritums, savukārt Zemgales reǵionā - pozitīvas tendences. Šādi procesi skaidrojami ar to, ka vienā tautsaimniecības jomā dažādas situācijas veidojas, vadoties no šīs jomas struktūras pazīmēm un pārstāvēto uzṇēmumu darbības veida. Ir skaidri redzams, ka Rīgā izmitināšanas un ēdināšanas pakalpojumi ir vērsti galvenokārt uz tūrismu un arī uz biznesa klientu apkalpošanu, taču Zemgales fokusā ir iekšējais tūrisms, lauku tūrisms un atpūta ǵimenēm, kas Covid-19 pandēmijas apstākḷos varēja sekmīgi izdzīvot.

Visbūtiskāk tiek traumēta individuālo pakalpojumu sfēra, kurā ietilpa vairums pašnodarbināto personu, un arī pakalpojumu sniegšana, šāda veida darbībai visos reǵionos ir negatīva tendence, īpaši kritiska situācija ir Latgales un Pierīgas reǵionā.

Iegūtie aprēḳini un dati izvirza vismaz trīs būtiskus jautājumus, kas turpmāko virzību varētu iezīmēt pēcpandēmijas fāzē:

- svarīgi noskaidrot, cik daudz nozaru turpmāko transformāciju ietekmēs pasaulē notiekošie globālie izmaiņu procesi, vai strukturālās izmaiņas ir galvenokārt Covid-19 pandēmijas ietekmes rezultāts un kādā mērā transformāciju ietekmē valdības realizētā politika ekonomikas transformācijas laukā;

- visticamāk, visu faktoru mijiedarbība par galveno uzdevumu pašreizējos apstākḷos izvirza ne tik daudz skaidrot kāpēc?, bet gan $k \bar{a}$ ? - kā pārvarēt radušās problēmas un kā ievirzìt valsts tautsaimniecības sistēmas attīstību vēlamajā virzienā, kas ved uz ilgtspējīgu pastāvēšanu;

- attīstības virzieni ir svarīgi vairākās dimensijās - ne tikai valsts tautsaimniecības saturiskā virzienā (kuros pamatsegmentos, kurās to veidojošās ražošanas nozarēs un tajos ietilpstošās uzṇēmumu grupās), bet arī lokālā izvietojumā valstī, lai nodrošinātu ne tikai galvaspilsētas un tās tuvākās apkārtnes, bet arī visas valsts teritorijas vienmērīgāku attīstību pēcpandēmijas fāzē. Šāda pieeja veicinātu vienmērīgāku tautsaimniecības nozaru gan strukturālo, gan lokālo izvietojumu valstī.

Veicot papildu analīzi par tautsaimniecības pamatsegmentos nodarbināto lokālo izvietojumu (4. tabula) reǵionos, dati parāda, ka, neraugoties uz pandēmijas situāciju, ir pārāk augsta nodarbinātības koncentrēšanās galvaspilsētā un Pierīgas reǵionā. Gandrīz visās tautsaimniecības nozarēs ir vērojama darbaspēka koncentrācija Rīgas un Pierīgas reǵionā, izṇēmums ir lauksaimniecības un ieguves rūpniecības jomā. No vienas puses, tas skaidrojams ar to, ka uzṇēmējdarbības 
koncentrācija ir notikusi galvaspilsētā un reg̣ionu pilsētās, taču, no otras puses, var vērtēt, ka pandēmijas procesi varētu viest būtiskas pozitīvas izmaiņas šajā sadalījumā.

4. tabula. Tautsaimniecības pamatsegmentos strādājošo geogrāfiskais izvietojums valstī (\%, no tautsaimniecības pamatsegmentā nodarbinātajiem kopumā valstī)

\begin{tabular}{|c|c|c|c|c|c|c|c|}
\hline $\begin{array}{l}\text { Aizṇemtās darba vietas reǵionos pa darbības } \\
\text { veidiem } 2020 \text {. gada } 4 \text {. ceturkšņa beigās }\end{array}$ & 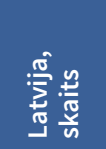 & 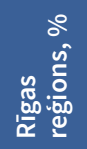 & 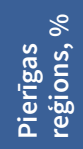 & 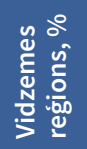 & 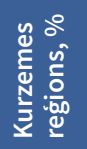 & 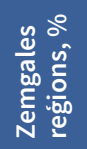 & 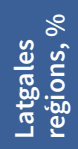 \\
\hline PAVISAM & 880639 & 54,27 & 15,19 & 6,54 & 8,63 & 7,62 & 7,75 \\
\hline $\begin{array}{l}\text { (A) Lauksaimniecība, mežsaimniecība un } \\
\text { zivsaimniecība }\end{array}$ & 21208 & 13,86 & 17,67 & 18,37 & 20,90 & 17,75 & 11,45 \\
\hline (B) leguves rūpniecība un karjeru izstrāde & 2789 & 1,69 & 29,94 & 14,56 & 19,76 & 23,99 & 10,08 \\
\hline (C) Apstrādes rūpniecība & 111897 & 32,50 & 22,15 & 9,66 & 14,06 & 11,54 & 10,09 \\
\hline $\begin{array}{l}\text { (D) Elektroenerĝija, gāzes apgāde, siltumapgāde } \\
\text { un gaisa kondicionēšana }\end{array}$ & 11768 & 49,97 & 10,93 & 9,87 & 6,00 & 9,30 & 13,93 \\
\hline $\begin{array}{l}\text { (E) Ūdens apgāde; notekūden̦u, atkritumu } \\
\text { apsaimniekošana un sanācija }\end{array}$ & 7570 & 34,60 & 23,13 & 7,98 & 10,58 & 14,65 & 9,08 \\
\hline (F) Būvniecība & 60881 & 46,76 & 17,79 & 6,88 & 11,30 & 9,81 & 7,45 \\
\hline $\begin{array}{l}\text { (G) Vairumtirdzniecība un mazumtirdzniecība; } \\
\text { automobilu un motociklu remonts }\end{array}$ & 139420 & 61,69 & 14,99 & 6,18 & 5,81 & 5,97 & 5,34 \\
\hline (H) Transports un uzglabāšana & 68471 & 52,19 & 23,15 & 3,67 & 9,23 & 4,64 & 7,11 \\
\hline (I) Izmitināšanas un ēdināšanas pakalpojumi & 24226 & 55,14 & 14,48 & 7,67 & 9,43 & 7,53 & 5,75 \\
\hline (J) Informācijas un komunikācijas pakalpojumi & 36735 & 85,97 & 7,00 & 1,28 & 2,46 & 1,14 & 2,16 \\
\hline (K) Finanšu un apdrošināšanas darbības & 16509 & 90,56 & 7,28 & 0,41 & 0,70 & 0,33 & 0,73 \\
\hline (L) Operācijas ar nekustamo īpašumu & 27955 & 61,12 & 13,76 & 3,55 & 7,06 & 5,21 & 9,29 \\
\hline $\begin{array}{l}\text { (M) Profesionālie, zinātniskie un tehniskie } \\
\text { pakalpojumi }\end{array}$ & 40405 & 71,71 & 11,72 & 4,76 & 3,95 & 5,37 & 2,49 \\
\hline $\begin{array}{l}\text { (N) Administratīvo un apkalpojošo dienestu } \\
\text { darbība }\end{array}$ & 37326 & 74,74 & 12,54 & 2,05 & 4,32 & 2,84 & 3,51 \\
\hline $\begin{array}{l}\text { (O) Valsts pārvalde un aizsardzība; obligātā } \\
\text { sociālā apdrošināšana }\end{array}$ & 63411 & 73,43 & 6,34 & 4,27 & 5,63 & 5,10 & 5,23 \\
\hline (P) Izglītība & 100826 & 41,85 & 15,10 & 8,79 & 10,96 & 10,60 & 12,69 \\
\hline (Q) Veselība un sociālā aprūpe & 73172 & 52,23 & 11,17 & 7,12 & 8,94 & 8,77 & 11,77 \\
\hline (R) Māksla, izklaide un atpūta & 23271 & 43,90 & 19,48 & 7,93 & 8,90 & 9,14 & 10,66 \\
\hline (S) Citi pakalpojumi & 12800 & 69,10 & 9,77 & 5,09 & 5,98 & 4,98 & 5,07 \\
\hline
\end{tabular}

Avots: CSP dati. Aizṇemtās darba vietas reǵionos pa darbības veidiem ceturkšṇa beigās (2020. gada 4. ceturksnis), autoru aprēḳini. ${ }^{17}$

17 Aizṇemtās darba vietas regiionos pa darbỉbas veidiem ceturkšņa beigās. Pieejams: https://data.csb.gov.lv/ pxweb/lv/sociala/sociala__aiznemtdv__isterm/JVS014c.px/table/tableViewLayout1/ [skatīts 20.03.2021.] 
Covid-19 pandēmijas ietekme uz darbaspēku vērtējama caur digitalizācijas procesa izvēršanās prizmu, līdz ar to attālināta darba iespējamības un e-komercijas pieaugums paver pieeju starptautiskajam tirgum un l̦auj izvērst zināšanās un tehnologijās balstìta darba iespējas arī Latvijas regionos un mazpilsētās. Turklāt kā pozitīvas sekas varētu būt tas, kas pandēmija deva impulsu veidot uzñēmumus ne tikai lielo pilsētu un mazpilsētu tuvumā, bet arī tradicionālās lauku teritorijās. Šāda iespējamība eksistē jau tagad, jo reǵionu novados sekmīgi darbojas gan augsto, gan vidēji augsto tehnolog̣iju uzṇēmumi, gan informācijas un komunikācijas institūcijas, taču līdz šim nebija impulsa to attīstībai tieši no patērētāju puses.

Lai sekmīgi pārvarētu ekonomiskajā darbībā radušās problēmas, daudz vairāk enerğijas jāvelta pozitīvās pieredzes apkopošanai par to uzņēmēju domāšanu un rīcỉbu, kas pašreizējās situācijas apstākḷ los ne tikai spējuši saglabāt, bet pat izvērst preces vai pakalpojuma izstrādi un iekarot lielāku vietu savas preces vai pakalpojuma noietam ārējā tirgū.

Detalizētāka šo izmainu analīze un nozīme būs tieši pēcpandēmijas procesā, lai varētu konstatēt maksimāli "cietušās" uzṇēmējdarbības lokālo izvietojumu un uzņēmējdarbības saturisko virzienu.

\section{Strukturālo izmaiṇu nākotnes scenāriji}

Vairākos EK ziņojumos un ieteikumos uzsvars tiek likts uz makroekonomiskās politikas ietekmi uz tautsaimniecības strukturālajām pārmaiņām. Tautsaimniecības atveseḷošanai pēc krīzes ir nepieciešama piemērotas monetārās politikas un zemo ilgtermiṇa procentu likmes noturēšana, labvēlīgu finansēšanas nosacỉjumu pakāpeniska un piesardzīga samazināšana un strukturālo reformu turpināšana. Tomēr globālās un Latvijas ekonomikas atvesel̦ošana ir l̦oti atkarīga no pandēmijas apkarošanas tempiem. Covid-19 pandēmijas scenāriji un to ietekme uz tautsaimniecības strukturālajām izmaiṇām ir parādīta 5. tabulā.

Vērtējot 5. tabulā apkopotos scenārijus, varam tikai minēt un akcentēt būtiskākos aspektus, kas var kalpot kā ietekmējošais faktors viena vai otra scenārija ìstenošanā. Gan makrovides veicināšanas, gan mikrovides savstarpējā mijiedarbība būs aktīvs noteicošais spēks, lai varētu strauji pāriet no negatīvā scenārija uz pozitīvo, kur būs šādi nozīmīgi akcenti:

- uzṇēmējdarbības ien̦ēmumu un mājsaimniecỉbu ienākumu ietekme var pārvērst veselības krīzi un īslaicīgu ekonomiskās aktivitātes samazināšanu par ilgtermiņa finanšu krīzi;

- cenu spiediens pamatā joprojām ir neliels, un to kontrolē plašā rezerves jauda visā pasaulē; 


\section{5. tabula. Covid-19 pandēmijas scenāriji un to ietekme uz tautsaimniecības strukturālajām izmaiṇām}

\begin{tabular}{|c|c|c|c|c|c|}
\hline \multicolumn{2}{|c|}{ 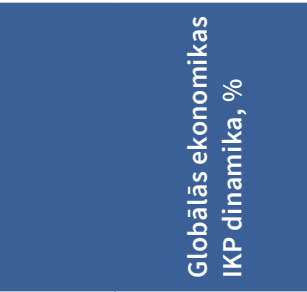 } & 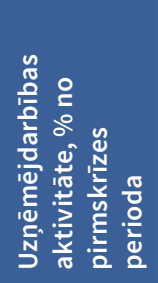 & 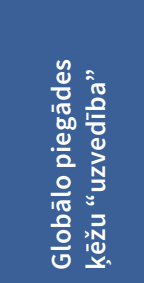 & 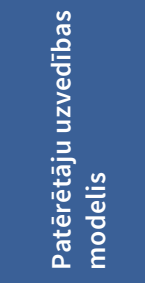 & 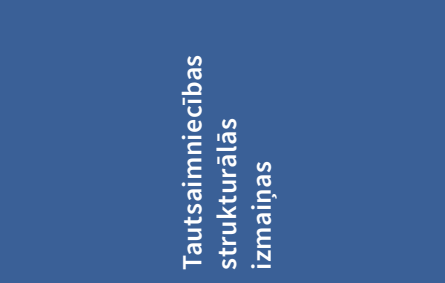 \\
\hline O & $-1,5 \% \ldots 0 \%$ & $70-50 \%$ & letekmēta & letekmēts & $\begin{array}{l}\text { Tautsaimniecība piedzīvo nelielas } \\
\text { gan lineārās, gan strukturālās } \\
\text { izmaiñas, kas vērstas vairāk uz } \\
\text { uzñēmējdarbības diversifikāciju un } \\
\text { integrāciju. Strukturālās pārmaiṇas } \\
\text { vairāk skar atsevišķus reğionus. }\end{array}$ \\
\hline 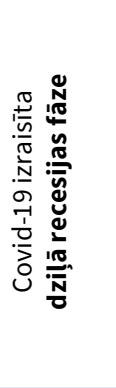 & $-3,5 \% \ldots-1,5 \%$ & $60-30 \%$ & Traucēta & Mainīts & $\begin{array}{l}\text { Tautsaimniecībā notiek būtiskas } \\
\text { izmaiñas, īpaši atsevišk̦u nozaru } \\
\text { skatījumā. Veidojas nozaru } \\
\text { attīstības “šķēres”. Ir nozares, } \\
\text { kas piedzīvo attīstību, jo } \\
\text { mainās patērētāju uzvedība un } \\
\text { pieprasījums. Ir nozares, kas slīgst } \\
\text { recesijā, jo pieprasījums pandēmijas } \\
\text { apstākļos ir minimāls. Strukturālās } \\
\text { nozaru pārmaiñas vērtējamas } \\
\text { starptautiskā dimensijā. }\end{array}$ \\
\hline 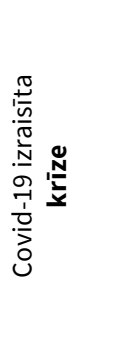 & $-5,5 \% \ldots-3,5 \%$ & $30-20 \%$ & $\begin{array}{l}\text { Būtiski } \\
\text { traucēta/ } \\
\text { pāreja uz } \\
\text { ìsākām } \\
\text { piegādes } \\
\text { k̦ēdēm }\end{array}$ & $\begin{array}{l}\text { Radikāli } \\
\text { mainīts }\end{array}$ & $\begin{array}{l}\text { Tautsaimniecības nozaru } \\
\text { strukturālās izmaiņas vairāk } \\
\text { orientētas uz saplūšanas un } \\
\text { sašķelšanās procesiem, kas } \\
\text { orientēti uz jaunu biznesa } \\
\text { model̦u izveidi uzṇēmējdarbībā. } \\
\text { Strukturālās izmainnas norit, } \\
\text { paralēli koncentrējoties gan uz } \\
\text { regionālajām, gan starptautiskajām } \\
\text { dimensijām. }\end{array}$ \\
\hline 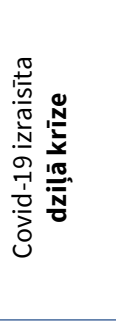 & $-9,0 \% \ldots-5,5 \%$ & Zem $20 \%$ & Paralizēta & Nenoteikts & $\begin{array}{l}\text { Tautsaimniecības nozaru pilnīga } \\
\text { pārstrukturizācija gan lineārā, gan } \\
\text { strukturālā nozīmē. Paralēli tiek } \\
\text { ieviesti vairāki biznesa model̦i, kas } \\
\text { orientēti uz pielāgošanās stratēǵiju } \\
\text { pandēmijas apstākḷiem. Atsevišķas } \\
\text { nozares paralēli var darboties } \\
\text { reǵionālajās, starptautiskajās un } \\
\text { globālajās dimensijās. }\end{array}$ \\
\hline 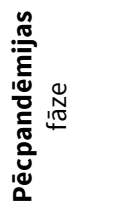 & $0 \% \ldots 1,5 \%$ & $100-70 \%$ & $\begin{array}{l}\text { Piegādes } \\
\text { kēžu stabi- } \\
\text { lizācija un } \\
\text { pārmaiñu } \\
\text { pazìmes }\end{array}$ & $\begin{array}{l}\text { Patēriņa } \\
\text { izmaiñu un } \\
\text { paraduma } \\
\text { maiñu } \\
\text { fiksācija }\end{array}$ & $\begin{array}{l}\text { Tautsaimniecības nozaru “jaunā } \\
\text { stabilitāte”, kas nozīmē situācijas } \\
\text { apzināšanos un nozaru darbības } \\
\text { atjaunošanos, pielāgojoties jaunajai } \\
\text { realitātei. }\end{array}$ \\
\hline
\end{tabular}




\begin{tabular}{|c|c|c|c|c|c|}
\hline 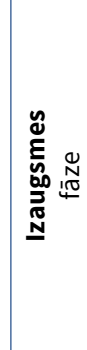 & $1,5 \ldots 3 \%$ & $\begin{array}{l}\text { Nav } \\
\text { prognožu }\end{array}$ & $\begin{array}{l}\text { Struk- } \\
\text { turālas } \\
\text { izmaiñas } \\
\text { piegādes } \\
\text { ķēdēs }\end{array}$ & $\begin{array}{l}\text { Patēriņa } \\
\text { paradumu } \\
\text { maiña } \\
\text { salīdzinā- } \\
\text { jumā ar } \\
\text { pirmspan- } \\
\text { dēmijas } \\
\text { periodu }\end{array}$ & $\begin{array}{l}\text { Tautsaimniecības dinamiskas } \\
\text { strukturālas izmaiñas, sekojot } \\
\text { piegādes k̦ēžu, patēriņa paradumu } \\
\text { izmaiṇām un jaunai tirgus } \\
\text { situācijai. Vērojama noteiktu } \\
\text { nozaru hiperaktivitāte un citu } \\
\text { nozaru lineāru, strukturālu } \\
\text { un transformācijas izmaiñu } \\
\text { (konsolidācijas, sadrumstalotības, } \\
\text { reǵionalizācijas u. c.) procesi. }\end{array}$ \\
\hline
\end{tabular}

Avots: autoru veidots, balstoties uz McKinsey ${ }^{18}$, Pasaules Ekonomikas foruma ${ }^{19}$ un Eiropas Komisijas datiem ${ }^{20}$ un prognozēm.

- spēcīgs pieprasījuma pieaugums zināmā mērā var palielināt inflāciju, taču elastīgajai vidējās inflācijas mērḳēšanas sistēmai būtu jālauj to pielāgot bez tūlìtējas politikas procentu likmju paaugstināšanas;

- vairākās valstīs pastāv iespējas vēl vairāk atvieglot procentu likmes, kur fiskālais atbalsts ir ierobežots, ja vien ir iespējams ierobežot preču cenu augstāku ietekmi uz inflāciju un valūtas kursi saglabājas stabili;

- fiskālie pasākumi, piemēram, plānotie publiskās infrastruktūras ieguldījumi, ieguldījumi digitālajos tīklos, transportā un enerǵètikā, var palīdzēt atbalstìt pieprasījumu, uzlabot produktivitāti un būt nozīmīgs jaunu darba vietu avots tiem darba ṇēmējiem, kuru nozarēs šobrīd ir vērojama lejupslīde vai dīkstāve;

- šajā periodā atbalstāmas ir tās rīcības, kas ekonomikas atveseḷošanā iekḷauj nepieciešamās darbības, lai veicinātu nozaru reformas atjaunojamo enerğijas avotu cirkulārās ekonomikas un klimata pārmaiṇu ilgtermiṇa draudu novēršanai. Nozarēm specifiskiem finansiālā atbalsta pasākumiem arī turpmāk vajadzētu būt atkarīgiem no vides uzlabojumiem un tām nozarēm, kuras spiestas veikt strukturālas pārmaiṇas, lai pēcpandēmijas un turpmākā izaugsmes fāzē būtu konkurētspējīgas;

- tiecoties pēc arvien lielākas efektivitātes, daudzi uzṇēmumi uzsver piegādes ķēžu elastību un noturību, kas Covid-19 pandēmijas laikā būtiski ir traucētas, un pēcpandēmijas prognozes liecina, ka piegādes ķēdes varētu piedzìvot nozīmīgu transformāciju un līdz ar to mainìt nozaru akcentus un izaugsmes tendences arī turpmāk.

18 McKinsey \& Company. (2021, March 31). A strategic vision for model risk management (by Laurent, M.-P., Raggl, A., Rougeaux, C., and Tejada, M.). Pieejams: https://www.mckinsey.com/business-functions/risk/our-insights/a-strategic-vision-for-model-risk-management

19 Chief Economists Outlook 2021. Pieejams: https://www.weforum.org/reports/chief-economistsoutlook- 2021

20 Eurostat. Pieejams: https://ec.europa.eu/eurostat/web/covid-19/economy 